\title{
Mensaje de la Directora del Instituto de Estudios Internacionales
}

Un motivo muy especial justifica que me asome a las páginas de la revista. En efecto, se ha considerado oportuno dedicar este número especial, cuyo tema central es América Latina, al profesor Gustavo Lagos, académico del Instituto de Estudios Internacionales que durante muchos años contribuyó con su preclaro conocimiento y destacadas condiciones profesionales a iniciar y profundizar el estudio y la enseñanza de las relaciones internacionales. Es una deuda de gratitud para quien nos abandona ahora para acogerse a un merecido descanso, dejando tras de sí la huella de su entrega a esta disciplina, con la satisfacción de haber formado generaciones de especialistas agradecidos.

Si correspondiera mayor explicación para este homenaje, cabe señalar que Gustavo Lagos fue profesor de varios de los autores que nos han entregado su saber para enriquecer el contenido de este número especial de la revista Estudios Internacionales. Estoy cierta de que no sólo ellos sino todos los lectores de nuestra publicación coincidirán en que es una manera, por modesta que sea, de intentar honrar al intelectual, académico y maestro de las relaciones internacionales.

Creo que no podría darse mejor homenaje para quien fuera nuestro profesor y nuestro predecesor en las tareas del Instituto de Estudios Internacionales. Para ese gran académico que hoy se retira de sus actividades cotidianas, pero que se mantendrá anclado a este Instituto con su pensamiento y con su obra. 